\title{
Feed Utilisation Efficiency of Lupin Inclusion in Cobia: Role of Dietary Organic Selenium Supplementation
}

\author{
Hung Duc Pham ${ }^{1,2}$, Ravi Fotedar ${ }^{1}$, Chau Minh Nguyen ${ }^{3} \&$ Muhammad Abu Bakar Siddik ${ }^{1}$ \\ ${ }^{1}$ Department of Environment and Agriculture, Curtin University, 01 Turner Avenue, Bentley, WA 6102, Australia \\ ${ }^{2}$ Institutes of Aquaculture, Nha Trang University, 02 Nguyen Dinh Chieu, Nha Trang, Khanh Hoa, Vietnam \\ ${ }^{3}$ Research Institute for Aquaculture No 3, 33 Dang Tat, Nha Trang, Khanh Hoa, Vietnam \\ Correspondence: Hung Duc Pham, Department of Environment and Agriculture, Curtin University, 01 Turner \\ Avenue, Bentley, WA 6102, Australia. Tel: 61-9266-4508. E-mail: pdhunguof@gmail.com
}

Received: May 16, 2016

doi:10.5539/mas.v10n10p180
Accepted: June 8, 2016

Online Published: July 27, 2016

URL: http://dx.doi.org/10.5539/mas.v10n10p180

\begin{abstract}
The dietary selenium (Se) requirement has been determined for cobia Rachycentron canadum using purified diet; however, its role in the utilisation of plant-derived ingredients has not been evaluated in the species. Therefore, a $3 \times 2$ factorial experimental design involving three inclusion levels $(0,210$ and $315 \mathrm{~g} / \mathrm{kg})$ of lupin Lupinus angustifolius kernel meal (LKM) and two concentrations $(0$ and $0.8 \mathrm{mg} / \mathrm{kg}$ ) of Se was used to evaluate the effects of Se supplementation in conjunction with LKM on the growth, feed utilisation and physiological responses in the cobia. Six isonitrogenous ( $46.5 \%$ crude protein) and isoenergetic $(21 \mathrm{MJ} / \mathrm{kg}$ gross energy) diets were formulated and fed to cobia for 7 weeks in a flow-through seawater system. The results showed significant effects of Se supplementation and its interaction with dietary lupin on the growth and feed efficiency of cobia. Se supplementation significantly improved the growth and feed utilisation efficiency in cobia fed lupin-based diets. The nutrient digestibility of fish fed supplemental Se lupin-based diets was significantly higher than that of fish fed diets without Se supplementation at each inclusion level of LKM. There were no significant effects of dietary Se supplementation on the survival, muscle composition or muscle amino acids, whereas regression analysis indicated a positive linear relationship between tissue Se accumulation and dietary Se levels. An enhancement of haematological responses was also observed in cobia fed Se-supplemented diets. In summary, cobia fed lupin-based diets required higher dietary Se supplementation for higher feed utilisation efficiency than previously quantified for the casein-based diet.
\end{abstract}

Keywords: organic selenium, cobia, lupin, feed utilisation

\section{Introduction}

Carnivorous marine fish such as cobia Rachycentron canadum require relatively high dietary protein to provide adequate amino acids and nitrogen for the synthesis of non-essential amino acids and other essential biological compounds (Fraser \& Davies, 2009). Fishmeal contains significantly high protein content, with well-balanced essential amino acids, and high nutrient digestibility to meet the nutritional requirements of fish (Gatlin et al., 2007). However, the rapid development of aquaculture has led to an increased demand and unstable supply of fishmeal (Olsen \& Hasan, 2012; Tacon \& Metian, 2008). A series of studies have evaluated the use of plant-derived ingredients to reduce the fishmeal dependence in cobia diets (Chou et al., 2004; Luo et al., 2012; Salze, McLean, Battle, Schwarz, \& Craig, 2010; Zhou, Mai, Tan, \& Liu, 2005). Chou et al. (2004) demonstrated that up to $40 \%$ of fishmeal protein can be replaced with soybean meal without compromising growth and feed utilisation, whereas, the replacement levels are $50 \%$ and $94 \%$ with soy-derived protein and soy protein concentrate, respectively (Salze et al., 2010; Trushenski et al., 2011). The optimal dietary rapeseed meal, corn gluten meal and yeast-based products in cobia diets were 135, 300 and $250 \mathrm{~g} / \mathrm{kg}$, respectively (Lunger, Craig, \& McLean, 2006; Luo et al., 2012; Luo et al., 2013). Our previous study (unpublished) also demonstrated the beneficial effects of narrow-leafed lupin kernel meal, wherein up to $105 \mathrm{~g} / \mathrm{kg}$ lupin kernel meal can be incorporated into the cobia diet without impairing specific growth rate and feed efficiency. However, the lysine and methionine limitations and the presence of anti-nutritional factors in lupin products can impair growth and feed utilisation (Carter \& Hauler, 2000; Farhangi \& Carter, 2001). Fishmeal-substituted diets can also result in histopathological lesions in the stomach, liver and intestine of the host farmed fish (Refstie et al., 2006; Robaina 
et al., 1995).

The increased inclusion levels of plant-derived ingredients in aqua-feeds can impact the uptake and digestion of minerals, consequently changing the mineral requirements of the fish (Antony Jesu Prabhu, Schrama, \& Kaushik, 2014; Barrows, Gaylord, Sealey, Smith, \& Porter, 2010; Read et al., 2014). The anti-nutritional factors presented in plant-derived ingredients can also interact with minerals, making these minerals less available for fish (Antony Jesu Prabhu et al., 2014). The interaction between phytic acid and minerals directly affects the digestion of minerals in fish. Whereas, the metabolised process of minerals can be disrupted due to the presence of other anti-nutrients (Antony Jesu Prabhu et al., 2014), thus, reducing nutrient digestibility (Petterson, 2000).

Selenium (Se) is an essential trace mineral for normal growth and physiological functions in animals (Watanabe, Kiron, \& Satoh, 1997). The deficiency of Se can cause negative effects on growth and survival, peroxidative damage to cells and their membranes and reduced host defence function in farmed fish (Liu, Wang, Ai, Mai, \& Zhang, 2010) (Lin \& Shiau, 2005; Liu et al., 2010). Feed ingredients contain varied amounts of Se, with relatively lower Se contents in plant-derived products than in fishmeal (Antony Jesu Prabhu et al., 2014; Watanabe et al., 1997). Additionally, the low Se level in lupin meal $(18-240 \mu \mathrm{g} / \mathrm{kg})$ in Australia due to the low Se concentration in Australian soils (Petterson, 2000) results in inadequate Se in the diets when fishmeal protein is replaced with lupin meal protein. The reduction of growth and feed efficiency caused by deficient dietary Se in lupin-based diets has been reported in barramundi Lates calcarifer (Ilham, Fotedar, \& Munilkumar, 2016). Whereas, rainbow trout Oncorhynchus mykiss fry fed soybean-based diets required Se fortification to achieve optimum glutathione peroxidase (GPx) activity (Fontagné-Dicharry et al., 2015). African catfish Clarias gariepinus (Abdel-Tawwab, Mousa, \& Abbass, 2007) and barramundi (Ilham et al., 2016) also showed improved growth performance, feed utilization and health after being fed plant-based diets supplemented with organic Se. Although dietary Se required for juvenile cobia fed casein-based diet has been quantified to be $0.788 \mathrm{mg} / \mathrm{kg}$ based on the specific growth rate (Liu et al., 2010). The fish fed plant-based diets could require mineral supplementation at higher concentrations than recommended by the National Research Council NRC (1993) (Barrows et al., 2010; Read et al., 2014). Besides, there is no published information on the interactive biological effects of dietary Se and dietary inclusion levels of LKM on cobia. Therefore, the aim of this study was to evaluate the effects of dietary Se supplementation on the nutritional and physiological responses in cobia fed high inclusion levels of narrow-leafed LKM.

\section{Materials and Methods}

\subsection{Experimental Diet Preparation}

The fishmeal protein in the control diet (LP0) was replaced with $40 \%$ and $60 \%$ of narrow-leafed lupin kernel meal (LKM) protein without and with $0.8 \mathrm{mg} / \mathrm{kg}$ Se extracted from Se-yeast (Sel-Plex, Alltech, Nicholasville, KY, USA) supplementation to formulate six isonitroenous and isoenergetic test diets, labelled as LP0, LP0Se, LP40, LP40Se, LP60 and LP60Se, respectively. The ingredients were finely grounded, and then homogeneously mixed. Chromic oxide $\left(\mathrm{Cr}_{2} \mathrm{O}_{3}\right)$ was added to all test diets as the inner marker. Taurine (Sigma-Aldrich, St. Louis, MO, USA) was added to all diets at a level of $5 \mathrm{~g} / \mathrm{kg}$ to meet the nutritional requirement of cobia as the recommendation by Watson, Barrows, and Place (2014). Fish oil and distilled water were added and then thoroughly mixed. A laboratory extruder was used to pelletise the diet through $2 \mathrm{~mm}$ die. The diets were air-dried, sealed in bags and stored in a freezer until feeding trial commenced. The diet formulation and ingredient composition are presented in Table 1 and Table 2.

\subsection{Experimental Fish}

Juvenile cobia was obtained from a commercial hatchery in Khanh Hoa Province, Vietnam. Fish was acclimated to the experimental conditions in two weeks prior to the commencement of the feeding trial. During this period, the fish were fed a commercial cobia diet (NRD P16, INVE Ltd, Thailand) containing $53 \%$ protein, $12 \%$ lipid and $21.0 \mathrm{MJ} / \mathrm{kg}$ gross energy. Prior to the test feeding, all fish were individually weighed and standard length measured after starving them for 24 hours. The cobia (initial mean weight of $18.56 \mathrm{~g} / \mathrm{fish}$ ) was randomly distributed to eighteen tanks at a density of 12 fish per tank. Each test diet was assigned to three tanks. Fish were hand-fed twice daily at 8:00 and 16:00 until apparent satiation for 7 weeks. Water temperature, dissolved oxygen and $\mathrm{pH}$ were measured daily using OxyGuard meters (Handy Polaris 2 and Handy $\mathrm{pH}$, OxyGuard International A/S, Denmark). Total ammonia was monitored with $\mathrm{NH}_{3} / \mathrm{NH}_{4}{ }^{+}$test kit (Mars Fishcare, Chalfont, PA, USA).

\subsection{Sample Collection}

At the beginning of the feeding trial, 15 fish were randomly selected for the initial whole body composition analysis. At the end of the experiment, three fish per tank were randomly sampled and stored in a freezer for the 
chemical analysis. Another three fish were used to collect blood samples by puncturing their caudal vein with a 25-gauge needle attached to a 1-ml syringe and transferred to the BD Vacutainer (with K2E $5.4 \mathrm{mg}$, UK) for haematological analysis. The muscle tissues from four fish per tank were pooled and used for proximate composition, selenium content and amino acid analysis. Faeces were collected following the method described by Kim, Tibbetts, Milley, and Lall (2007). One hour after the last feeding, air diffusers, and the bottom and walls of the tanks were carefully cleaned to remove any residual feed and waste from the rearing system. Faeces were allowed to settle overnight. The faeces were gently collected into a $200 \mathrm{~mL}$ polyethylene bottle in the following morning, and then were centrifuged for $20 \mathrm{~min}$ at $10000 \mathrm{rpm}$, before the supernatant was discarded; the faecal material was stored at $-20{ }^{\circ} \mathrm{C}$ until analysis.

Table 1. Ingredients and composition of the experimental diets ( $\mathrm{g} \mathrm{kg}^{-1}$ in dry weight)

\begin{tabular}{|c|c|c|c|c|c|c|}
\hline \multirow{2}{*}{ Ingredients $^{\mathrm{a}}$} & \multicolumn{6}{|l|}{ Diets } \\
\hline & LP0 & LP0Se & LP40 & LP40Se & LP60 & LP60Se \\
\hline Fishmeal & 320 & 320 & 192 & 192 & 128 & 128 \\
\hline Soybean meal & 100 & 100 & 100 & 100 & 100 & 100 \\
\hline Lupin kernel meal & 0 & 0 & 210 & 210 & 315 & 315 \\
\hline Casein & 146 & 146 & 146 & 146 & 146 & 146 \\
\hline Wheat flour & 5 & 5 & 5 & 5 & 5 & 5 \\
\hline Wheat gluten & 120 & 120 & 120 & 120 & 120 & 120 \\
\hline Cellulose & 159 & 157.5 & 77 & 75.5 & 36 & 34.5 \\
\hline Wheat starch & 30 & 30 & 30 & 30 & 30 & 30 \\
\hline Fish oil & 95 & 95 & 95 & 95 & 95 & 95 \\
\hline Taurine $^{\mathrm{b}}$ & 5 & 5 & 5 & 5 & 5 & 5 \\
\hline Premix ${ }^{c}$ & 15 & 15 & 15 & 15 & 15 & 15 \\
\hline Sel-Plex ${ }^{d}$ & 0 & 1.5 & 0 & 1.5 & 0 & 1.5 \\
\hline Chromic oxide $^{\mathrm{e}}$ & 5 & 5 & 5 & 5 & 5 & 5 \\
\hline \multicolumn{7}{|c|}{ Proximate composition } \\
\hline Moisture (\%) & 8.82 & 8.66 & 10.29 & 11.79 & 9.56 & 10.02 \\
\hline Crude protein $(\%)$ & 46.51 & 46.64 & 46.85 & 46.24 & 46.71 & 46.54 \\
\hline Crude lipid (\%) & 11.42 & 11.94 & 11.35 & 11.07 & 10.97 & 10.12 \\
\hline Ash (\%) & 8.10 & 7.09 & 6.46 & 5.72 & 4.53 & 4.58 \\
\hline Gross energy $(\mathrm{MJ} / \mathrm{kg})$ & 20.85 & 20.78 & 21.38 & 21.36 & 22.18 & 22.21 \\
\hline $\mathrm{Se}(\mathrm{mg} / \mathrm{kg})$ & 1.71 & 2.42 & 1.28 & 2.04 & 1.03 & 1.82 \\
\hline Phytic acid (g/kg) & 2.51 & 2.48 & 3.58 & 3.61 & 3.94 & 4.01 \\
\hline Tannins $(\mathrm{g} / \mathrm{kg})$ & 0.35 & 0.33 & 0.61 & 0.63 & 0.91 & 0.90 \\
\hline \multicolumn{7}{|c|}{ Essential amino acids } \\
\hline Arginine & 2.78 & 2.78 & 3.17 & 3.17 & 3.37 & 3.36 \\
\hline Histidine & 1.45 & 1.46 & 1.39 & 1.38 & 1.34 & 1.35 \\
\hline Isoleucine & 2.29 & 2.27 & 2.31 & 2.31 & 2.36 & 2.37 \\
\hline Leucine & 4.31 & 4.34 & 4.22 & 4.21 & 4.18 & 4.20 \\
\hline Lysine & 3.06 & 3.06 & 2.81 & 2.80 & 2.61 & 2.59 \\
\hline Methionine & 1.33 & 1.31 & 1.14 & 1.13 & 1.05 & 1.06 \\
\hline Phenylalanine & 2.41 & 2.42 & 2.38 & 2.40 & 2.40 & 2.41 \\
\hline Threonine & 2.26 & 2.26 & 2.14 & 2.15 & 2.13 & 2.12 \\
\hline Valine & 2.60 & 2.61 & 2.61 & 2.62 & 2.63 & 2.63 \\
\hline Taurine & 0.42 & 0.41 & 0.43 & 0.41 & 0.39 & 0.40 \\
\hline
\end{tabular}

Note. Supplied by Specialty Feeds (Glen Forrest, WA 6071, and Australia)

Sigma-Aldrich, St. Louis, MO, USA

Contains the following (as $\mathrm{g} / \mathrm{kg}$ of premix): iron, 10; copper, 1.5; iodine, 0.15 ; manganese, 9.5; zinc, 25; vitamin A retinol, $100 \mathrm{IU}$; vitamin $\mathrm{D} 3,100 \mathrm{IU}$; vitamin $\mathrm{E}, 6.25$; vitamin $\mathrm{K}, 1.6$; vitamin $\mathrm{B} 1$, 1; vitamin $\mathrm{B} 2$, 2.5; niacin, 20; vitamin B6, 1.5; calcium, 5.5; biotin, 0.1; folic acid, 0.4; inositol, 60; vitamin B12, 0.002; choline, 150; and ethoxyquin, 0.125

Obtained from Alltech, Nicholasville, KY, USA

Obtained from Thermo Fisher Scientific, Scoresby, Victoria, Australia. 
Table 2. Feed ingredient composition ( $\mathrm{g} / 100 \mathrm{~g}$ or $\mathrm{MJ} / \mathrm{kg}$ in dry matter) unless specified

\begin{tabular}{cccccccccc}
\hline $\begin{array}{c}\text { Ingredients } \\
\mathrm{a}\end{array}$ & $\begin{array}{c}\text { Crude } \\
\text { protein }\end{array}$ & $\begin{array}{c}\text { Total } \\
\text { lipid }\end{array}$ & Ash & $\begin{array}{c}\text { Dry } \\
\text { matter }\end{array}$ & $\begin{array}{c}\text { Organic } \\
\text { matter }^{\mathrm{b}}\end{array}$ & $\begin{array}{c}\text { Gross } \\
\text { energy }\end{array}$ & $\begin{array}{c}\mathrm{Se} \\
(\mathrm{mg} / \mathrm{kg})\end{array}$ & $\begin{array}{c}\text { Phytic } \\
\text { acid }\end{array}$ & Tannins \\
\hline $\begin{array}{c}\text { Fishmeal } \\
\text { Lupin meal }\end{array}$ & 64.00 & 10.70 & 21.90 & 91.43 & 78.10 & 20.09 & 4.37 & $\mathrm{n} / \mathrm{d}$ & $\mathrm{n} / \mathrm{d}$ \\
& 6.82 & 2.41 & 87.61 & 97.59 & 20.93 & 0.35 & 0.53 & 0.16 \\
\hline
\end{tabular}

Note. $\mathrm{n} / \mathrm{d}$ : not detected.

\subsection{Chemical Analysis}

Crude protein, crude lipid, moisture, ash and gross energy contents of the whole body and muscle tissues of cobia, faecal material and tested diets were determined according to the standard methods of AOAC (1990). The crude protein was determined by Kjeldahl method; crude lipid was analysed gravimetrically following chloroform : methanol extraction of the lipids according to the method of Folch, Lees, and Sloane-Stanley (1957); moisture by drying at $105^{\circ} \mathrm{C}$ in an oven (Thermotec 2000, Contherm Scientific, Hutt, New Zealand) to a constant weight; ash by combustion at $550{ }^{\circ} \mathrm{C}$ for $24 \mathrm{~h}$ in an electric furnace (Carbolite, S., UK); and gross energy was determined by bomb calorimeter (C2000, IKA, Staufen, Germany). The tannin was analysed following the method described by Embaby (2011) after extraction in acetone. Phytic acid in phytate salt form was analysed after extraction in hydrochloric acid following the procedure from Haddad, Greiner, and Allaf (2007). The selenium content in the test diets and muscle tissues were analysed following inductively coupled plasma atomic absorption spectrometry. Chromic oxide was determined by the method from Bolin, King, and Klosterman (1952) using a spectrophotometer (UV-1201, Shimadzu, K., Japan). Amino acid profiles were analysed by using high performance liquid chromatography after an acid hydrolysis. Blood constituents were automatically analysed using automated haematology analyser (Sysmex XT-1800i, Kobe, Japan).

\subsection{Calculations and Statistical Analysis}

The survival rate, specific growth rate (SGR \%/day), feed conversion ratio (FCR), protein retention (PR) and energy retention (ER) were calculated using following equations:

$$
\begin{gathered}
\text { Survival }(\%)=100 \times \text { final fish number } / \text { initial fish number } \\
S G R=100 \times[(\text { Ln FBW }- \text { Ln IBW }) / \text { feeding period }(\text { days })]
\end{gathered}
$$

Where IBW and FBW are the initial body weight and final body weight, respectively.

$$
\begin{gathered}
F C R=\text { feed intake in dry matter }(g) / \text { body weight gain }(g) \\
P R=\text { protein gain } \times 100 / \text { protein fed } \\
E R=\text { energy gain } \times 100 / \text { energy fed }
\end{gathered}
$$

Apparent digestibility coefficient (ADC) of tested diets and basal diet were calculated as Equation (6) described by Cho, Slinger, and Bayley (1982):

$$
A D C \text { diet }=100 \times[1-(\text { Fnut } / \text { Dnut } x \text { DCr } / F C r)]
$$

Where $\mathrm{F}_{\text {nut }}$ is the $\%$ of nutrient or gross energy in faeces, $\mathrm{D}_{\text {nut }}$ represents $\%$ of nutrient or gross energy in the diet. $\mathrm{D}_{\mathrm{Cr}}$ and $\mathrm{F}_{\mathrm{Cr}}$ are \% of the chromic oxide in diet and faeces, respectively.

All data were statistically analysed using SPSS for Windows version 22 (IBM, New York, USA) unless otherwise specified. The two-way ANOVA was used to analyse the effects of dietary lupin meal inclusions, Se supplementation and their interactions on all of the tested parameters of cobia. When a significant main effect was observed, data were analysed to determine the differences among the dietary groups with or without Se supplementation. When a significant interaction was detected, one-way analysis (ANOVA) with post hoc Turkey's HSD multiple comparison tests were employed to determine differences among dietary treatments, but not for means of main effects. The linear regression analysis was used to determine the relationship between dietary Se level and Se accumulation in the tissues. The statistical significance was evaluated at $\mathrm{P}<0.05$.

\section{Results}

During the feeding trial, the water temperature ranged from 28 to $30{ }^{\circ} \mathrm{C}$, total ammonia was less than $0.5 \mathrm{mg} / \mathrm{L}$, and $\mathrm{pH}$ was $7.6-8.2$. The salinity ranged from 28 to $33 \%$.

\subsection{Growth Performances}

There were significant $(\mathrm{P}<0.05)$ effects of dietary LKM, Se supplementation and their interaction on the final weight (FBW), specific growth rate (SGR), feed intake (FI) and feed conversion ratio (FCR) of the cobia after 7 
weeks of feeding. In the absence of Se supplementation, cobia fed $315 \mathrm{~g} / \mathrm{kg}$ LKM resulted in a reduction in FBW, SGR and FI, whereas FCR was increased at an inclusion level of $210 \mathrm{~g} / \mathrm{kg}$ LKM. Fish fed lupin-based diets supplemented with $0.8 \mathrm{mg} / \mathrm{kg}$ Se achieved significantly higher FBW, SGR, FI and FCR than the fish fed lupin-based diets without Se supplementation (Table 3). Reduced protein retention (PR) and energy retention (ER) were observed in the fish fed lupin-based diets without Se supplementation. There was a significant effect of the interaction between dietary LKM and Se supplementation on the PR, but not on ER. High survival rates were attained in all dietary treatments and were not significantly $(\mathrm{P}>0.05)$ affected by dietary LKM, Se supplementation or their interaction (Table 3).

Table 3. Growth and feed utilisation of cobia fed the test diets

\begin{tabular}{|c|c|c|c|c|c|c|c|}
\hline Diet & FBW (g/fish) & SGR (\%/day) & FI (g/fish) & FCR & $\mathrm{PR}$ & ER & Survival (\%) \\
\hline LP0 & $84.46^{\text {cd }}$ & $3.11^{\text {cd }}$ & $92.08^{c}$ & $1.39^{\mathrm{a}}$ & $24.59^{\mathrm{d}}$ & 23.42 & 100 \\
\hline LP40 & $79.16^{\mathrm{c}}$ & $2.96^{\mathrm{c}}$ & $89.39^{c}$ & $1.48^{\mathrm{b}}$ & $23.36^{\mathrm{c}}$ & 21.56 & 100 \\
\hline LP60 & $61.55^{\mathrm{a}}$ & $2.44^{\mathrm{a}}$ & $68.64^{\mathrm{a}}$ & $1.60^{\mathrm{c}}$ & $20.19^{\mathrm{a}}$ & 19.28 & 97.22 \\
\hline LP0Se & $85.28^{\mathrm{d}}$ & $3.13^{\mathrm{d}}$ & $91.39^{c}$ & $1.37^{\mathrm{a}}$ & $25.22^{\mathrm{d}}$ & 23.66 & 97.22 \\
\hline LP40Se & $85.71^{\mathrm{d}}$ & $3.12^{\mathrm{d}}$ & $94.99^{c}$ & $1.42^{\mathrm{a}}$ & $24.68^{\mathrm{d}}$ & 22.37 & 100 \\
\hline LP60Se & $72.93^{\mathrm{b}}$ & $2.79^{\mathrm{b}}$ & $80.02^{\mathrm{b}}$ & $1.47^{\mathrm{b}}$ & $22.23^{\mathrm{b}}$ & 20.90 & 94.44 \\
\hline Pooled SE & 2.14 & 0.06 & 2.25 & 0.02 & 0.43 & 0.38 & 0.84 \\
\hline \multicolumn{8}{|c|}{ Means of main effects of fishmeal protein replacement level } \\
\hline 0 & 84.87 & 3.12 & 91.74 & 1.38 & 24.91 & $23.54^{\mathrm{C}}$ & 98.61 \\
\hline 40 & 82.44 & 3.04 & 92.19 & 1.45 & 24.02 & $21.96^{\mathrm{B}}$ & 100 \\
\hline 60 & 67.24 & 2.61 & 74.33 & 1.54 & 21.21 & $20.09^{\mathrm{A}}$ & 95.83 \\
\hline \multicolumn{8}{|c|}{ Means of main effects of dietary Se supplementation } \\
\hline 0 & 75.06 & 2.84 & 83.37 & 1.49 & 22.72 & $21.42^{\mathrm{X}}$ & 99.07 \\
\hline 0.8 & 81.31 & 3.01 & 88.80 & 1.42 & 24.04 & $22.31^{\mathrm{Y}}$ & 97.22 \\
\hline \multicolumn{8}{|c|}{ Two-way ANOVA: P values } \\
\hline Lupin & 0.000 & 0.000 & 0.000 & 0.000 & 0.000 & 0.000 & 0.139 \\
\hline $\mathrm{Se}$ & 0.000 & 0.000 & 0.000 & 0.000 & 0.000 & 0.002 & 0.271 \\
\hline Lupin $x \mathrm{Se}$ & 0.002 & 0.001 & 0.003 & 0.002 & 0.011 & 0.084 & 0.723 \\
\hline
\end{tabular}

Values are displayed as mean of triplicate groups. Means with different lowercase alphabets (a, b, c, d) within a column indicate the significantly differences $(\mathrm{P}<0.05)$ among all dietary treatments. Means with different uppercase alphabets $(\mathrm{A}, \mathrm{B}, \mathrm{C}$ or $\mathrm{X}, \mathrm{Y})$ within a column indicate the significantly differences $(\mathrm{P}<0.05)$ among means of the main effects of fishmeal replacement level and dietary Se supplementation, respectively. FW: Final weight (g), SGR: Specific growth rate, FI: Feed intake, FCR: Feed conversion ratio, PR: Protein retention and ER: Energy retention.

\subsection{Digestibility}

In the absence of Se supplementation, the cobia fed dietary LKM showed significantly lower nutrient digestibility than the fish fed the control diet. At each inclusion level of LKM, the digestibility of protein, energy and dry matter significantly improved when the diet was supplemented with Se. The interaction between dietary lupin and Se supplementation did not affect the protein, energy or dry matter digestibility of the cobia (Table 4).

\subsection{Haematological Parameters}

The haematocrit $(\mathrm{Ht})$ was significantly $(\mathrm{P}<0.05)$ affected by dietary Se supplementation, but not by dietary LKM levels. There were significant effects of dietary LKM level, Se supplementation and their interaction on the red blood cells (RBCs) and haemoglobin $(\mathrm{Hb})$ of the cobia at the end of the feeding period. In the absence of Se supplementation, the RBC and $\mathrm{Hb}$ concentrations were significantly reduced in the cobia fed $315 \mathrm{~g} / \mathrm{kg} \mathrm{LKM}$. However, the RBCs and $\mathrm{Hb}$ concentrations significantly increased in cobia fed $315 \mathrm{~g} / \mathrm{kg}$ LKM supplemented with Se compared with the fish fed the same diet without Se supplementation (Table 4). 
Table 4. Apparent digestibility coefficients (ADC) and haematological parameters of cobia fed test diets

\begin{tabular}{|c|c|c|c|c|c|c|}
\hline Diets & ADC of protein $(\%)$ & ADC of energy $(\%)$ & ADC of dry matter $(\%)$ & $\mathrm{Ht}(\%)$ & $\mathrm{RBC}$ & $\mathrm{Hb}$ \\
\hline LP0 & 87.80 & 75.04 & 67.17 & 42.15 & $4.24^{\mathrm{b}}$ & $7.16^{\mathrm{bc}}$ \\
\hline LP40 & 85.20 & 66.32 & 63.92 & 42.62 & $4.18^{\mathrm{b}}$ & $7.05^{\mathrm{b}}$ \\
\hline LP60 & 82.46 & 62.80 & 58.21 & 41.99 & $3.97^{\mathrm{a}}$ & $6.35^{\mathrm{a}}$ \\
\hline LPOSe & 89.42 & 76.35 & 69.63 & 43.55 & $4.31^{\mathrm{b}}$ & $7.28^{\mathrm{c}}$ \\
\hline LP40Se & 87.96 & 70.39 & 64.25 & 43.99 & $4.30^{\mathrm{b}}$ & $7.24^{\mathrm{bc}}$ \\
\hline LP60Se & 85.11 & 66.17 & 60.79 & 43.64 & $4.24^{\mathrm{b}}$ & $7.13^{\mathrm{bc}}$ \\
\hline Pooled SE & 0.59 & 1.21 & 0.95 & 0.31 & 0.03 & 0.33 \\
\hline \multicolumn{7}{|c|}{ Means of main effects of fishmeal protein replacement level } \\
\hline 0 & $88.61^{\mathrm{C}}$ & $75.69^{\mathrm{C}}$ & $68.40^{\mathrm{C}}$ & 42.85 & 4.28 & 7.22 \\
\hline 40 & $86.58^{\mathrm{B}}$ & $68.36^{\mathrm{B}}$ & $64.08^{\mathrm{B}}$ & 43.31 & 4.24 & 7.15 \\
\hline 60 & $83.79^{\mathrm{A}}$ & $64.49^{\mathrm{A}}$ & $59.50^{\mathrm{A}}$ & 42.82 & 4.11 & 6.74 \\
\hline \multicolumn{7}{|c|}{ Means of main effects of dietary Se supplementation } \\
\hline 0 & $85.15^{\mathrm{x}}$ & $68.06^{\mathrm{X}}$ & $63.10^{\mathrm{X}}$ & $42.26^{\mathrm{X}}$ & 4.13 & 6.86 \\
\hline 0.8 & $87.50^{\mathrm{Y}}$ & $70.97^{\mathrm{Y}}$ & $64.89^{\mathrm{Y}}$ & $43.73^{\mathrm{Y}}$ & 4.29 & 7.22 \\
\hline \multicolumn{7}{|c|}{ Two-way ANOVA: P values } \\
\hline Lupin & 0.000 & 0.000 & 0.000 & 0.744 & 0.001 & 0.000 \\
\hline $\mathrm{Se}$ & 0.002 & 0.000 & 0.008 & 0.025 & 0.000 & 0.000 \\
\hline Lupin $\mathrm{x} \mathrm{Se}$ & 0.990 & 0.126 & 0.230 & 0.977 & 0.024 & 0.000 \\
\hline
\end{tabular}

Values are displayed as mean of triplicate groups. Means with different lowercase alphabets (a, b, c, d) within a column indicate the significantly differences $(\mathrm{P}<0.05)$ among all dietary treatments. Means with different uppercase alphabets $(\mathrm{A}, \mathrm{B}, \mathrm{C}$ or $\mathrm{X}, \mathrm{Y})$ within a column indicate the significantly differences $(\mathrm{P}<0.05)$ among means of the main effects of fishmeal replacement level and dietary Se supplementation, respectively. Ht: haematocrit, RBC: Red blood cell, Hb: Haemoglobin.

\subsection{Proximate Composition}

Neither dietary LKM nor Se supplementation significantly $(\mathrm{P}>0.05)$ affected the protein, dry matter and ash contents in the muscle tissues of cobia. However, dietary LKM, but not Se supplementation, significantly affected the lipid content and gross energy in the muscles of the cobia (Table 5). The muscle amino acid profiles did not show any significant differences among treatments (Table 6). There were no significant effects due to the interaction between dietary lupin levels and Se supplementation on the muscle composition or amino acid profiles of the cobia at the end of the feeding period. Dietary LKM level, Se supplementation and their interaction had significant effects on Se deposition in the cobia tissues (Figure. 1). Regression analysis revealed positive linear relationships between dietary Se levels and tissue Se accumulation in cobia $(y=0.177 \mathrm{x}+0.1795$, $\mathrm{R}^{2}=0.9585$ with $\mathrm{P}<0.001$ for the muscle Se and $\mathrm{y}=0.5222 \mathrm{x}+0.6685, \mathrm{R}^{2}=0.9516$ with $\mathrm{P}<0.001$ for the liver $\mathrm{Se})$.

\section{Discussion}

In the absence of Se supplementation, cobia fed high dietary levels of LKM showed reduced FBW, SGR, FI and nutrient digestibility, corresponding to increased FCR. This was consistent when cobia were fed soybean meal (Chou et al., 2004; Zhou et al., 2005) and rapeseed meal (Luo et al., 2012). The reduced growth rates in cobia fed $315 \mathrm{~g} / \mathrm{kg}$ LKM can be linked to the depression in FI as FI is directly related to weight gain (Espe, El-Mowafi, \& Ruohonen, 2012). Therefore, it is essential to maintain an equal feed acceptability in order to evaluate the performance of the fishmeal-substituted diets (Espe et al., 2012).

The suppression of FI has been attributed to the deficiency of essential amino acids in lupin-based diets (Jobling et al., 2007). This is probably due to low concentrations of lysine and methionine in lupin products (Gatlin et al., 2007) as shown by relatively lower growth and feed efficiency in cobia by Zhou, Wu, Tan, Chi, and Yang (2006) and $\mathrm{Zhou}, \mathrm{Wu}, \mathrm{Chi}$, and Yang (2007). The dietary requirements for lysine and methionine of juvenile cobia are $2.33 \%$ and $1.05 \%$, respectively (Zhou et al., 2007; Zhou et al., 2006). Although lupin inclusion diets contain lower dietary lysine and methionine concentrations than fishmeal-based diets, however, the higher dietary lupin inclusion levels in the current study are still able to meet the threshold requirement of lysine and methionine for juvenile cobia. 
Table 5. The muscle compositions of cobia fed test diets

\begin{tabular}{|c|c|c|c|c|c|}
\hline Diet & Protein $(\%)$ & Lipid (\%) & Dry matter $(\%)$ & Ash (\%) & Gross energy $(\mathrm{MJ} / \mathrm{kg})$ \\
\hline LP0 & 18.22 & 2.41 & 23.57 & 1.51 & 5.45 \\
\hline LP40 & 18.08 & 2.41 & 22.88 & 1.55 & 5.28 \\
\hline LP60 & 17.98 & 2.31 & 22.24 & 1.58 & 5.10 \\
\hline LP0Se & 18.24 & 2.40 & 23.32 & 1.57 & 5.44 \\
\hline LP40Se & 18.19 & 2.43 & 22.96 & 1.59 & 5.32 \\
\hline LP60Se & 17.97 & 2.36 & 22.85 & 1.58 & 5.14 \\
\hline Pooled SE & 0.05 & 0.01 & 0.19 & 0.01 & 0.04 \\
\hline \multicolumn{6}{|c|}{ Means of main effects of fishmeal protein replacement level } \\
\hline 0 & 18.23 & $2.40^{\mathrm{B}}$ & 23.44 & 1.56 & $5.44^{\mathrm{B}}$ \\
\hline 40 & 18.14 & $2.42^{\mathrm{B}}$ & 23.08 & 1.57 & $5.30^{\mathrm{B}}$ \\
\hline 60 & 17.98 & $2.34^{\mathrm{A}}$ & 22.54 & 1.58 & $5.12^{\mathrm{A}}$ \\
\hline \multicolumn{6}{|c|}{ Means of main effects of dietary Se supplementation } \\
\hline 0 & 18.09 & 2.38 & 23.00 & 1.56 & 5.28 \\
\hline 0.8 & 18.13 & 2.39 & 23.04 & 1.58 & 5.31 \\
\hline \multicolumn{6}{|c|}{ Two-way ANOVA: P values } \\
\hline Lupin & 0.152 & 0.000 & 0.090 & 0.567 & 0.001 \\
\hline $\mathrm{Se}$ & 0.685 & 0.078 & 0.894 & 0.267 & 0.548 \\
\hline Lupin $x$ Se & 0.870 & 0.081 & 0.438 & 0.551 & 0.610 \\
\hline
\end{tabular}

Values are displayed as mean of triplicate groups. Means with different lowercase alphabets (a, b, c, d) within a column indicate the significant differences $(\mathrm{P}<0.05)$ among all dietary treatments. Means with different uppercase alphabets $(\mathrm{A}, \mathrm{B}, \mathrm{C})$ within a column indicate the significant differences $(\mathrm{P}<0.05)$ among means of the main effects of fishmeal replacement level.

Table 6. Essential amino acid profiles ( $\mathrm{g} / 100 \mathrm{~g}$ dry weight sample) in muscle of cobia fed test diets

\begin{tabular}{ccccccccccc}
\hline Diets & Arg & His & Iso & Leu & Lys & Met & Phe & Thr & Tyr & Valine \\
\hline LP0 & 3.16 & 2.43 & 4.10 & 6.57 & 9.22 & 2.01 & 3.15 & 2.43 & 2.94 & 3.96 \\
LP40 & 3.14 & 2.38 & 4.19 & 6.45 & 9.01 & 1.94 & 3.17 & 2.43 & 3.00 & 4.02 \\
LP60 & 3.14 & 2.37 & 4.04 & 6.67 & 9.25 & 1.94 & 3.20 & 2.41 & 2.95 & 3.98 \\
LP0 + Se & 3.15 & 2.39 & 4.17 & 6.68 & 9.01 & 2.06 & 3.23 & 2.44 & 2.99 & 3.96 \\
LP40+ Se & 3.13 & 2.42 & 4.20 & 6.67 & 9.26 & 1.90 & 3.19 & 2.42 & 2.95 & 3.98 \\
LP60 + Se & 2.81 & 2.36 & 4.12 & 6.65 & 9.23 & 1.98 & 3.27 & 2.41 & 2.97 & 3.94 \\
Pool SE & 0.06 & 0.01 & 0.02 & 0.01 & 0.04 & 0.02 & 0.02 & 0.01 & 0.01 & 0.02 \\
& \multicolumn{7}{c}{ Two-way ANOVA: P values } \\
Lupin & 0.39 & 0.25 & 0.15 & 0.37 & 0.43 & 0.17 & 0.60 & 0.13 & 0.84 & 0.67 \\
Se & 0.34 & 0.93 & 0.27 & 0.09 & 0.92 & 0.70 & 0.22 & 0.86 & 0.79 & 0.48 \\
Lupin x Se & 0.43 & 0.34 & 0.79 & 0.10 & 0.09 & 0.71 & 0.80 & 0.89 & 0.28 & 0.87 \\
\hline
\end{tabular}

Values are displayed as mean of triplicate groups. Means with same letters within a column are not significantly different $(\mathrm{P}>0.05)$. SEM: pool standard error of the mean.

The high inclusion levels of dietary plant-derived ingredients in aqua-feeds also result in an increased proportion of dietary anti-nutrients (Francis, Makkar, \& Becker, 2001; Gatlin et al., 2007). The interactions between anti-nutritional factors presented in protein ingredients and micronutrients can also impact the absorption and metabolism of these micronutrients (Read et al., 2014). The molecules in phytate can attach to minerals such as calcium, zinc, copper, iron, manganese, nickel and Se to form insoluble compounds, reducing the bioavailability of these minerals (Francis et al., 2001). The chelation between phytate and cation groups in protein, amino acids and lipid can also result in a reduction in the digestibility of these nutrients (Francis et al., 2001). Meanwhile, the metabolism of minerals in fish might also be compromised due to the presence of other anti-nutritional factors, such as tannin, saponin, glucosinolates and gossypol (Antony Jesu Prabhu et al., 2014). Thus, the complexity of mineral chelation may depress the growth, feed utilisation and mineral absorption in fish, as observed in Atlantic salmon Salmon salar (Storebakken, Shearer, \& Roem, 1998) and channel catfish Ictalurus punctatus (Satoh, Poe, \& Wilson, 1989). Relative to other plant ingredients, narrow-leafed LKM contains insignificant levels of phytic 
acid $(0.53 \%)$ and tannins $(0.16 \%)$, resulting in low dietary phytic acid and tannin concentrations in the test diets (Table 1). Besides, the saponins, trypsin and chymotrypsin inhibitors found in the narrow-leafed LKM at low levels $(574,0.12$ and $0.6 \mathrm{mg} / \mathrm{kg}$, respectively) are unlikely to interfere with the uptake and absorption of nutrients in fish (Petterson, 2000).
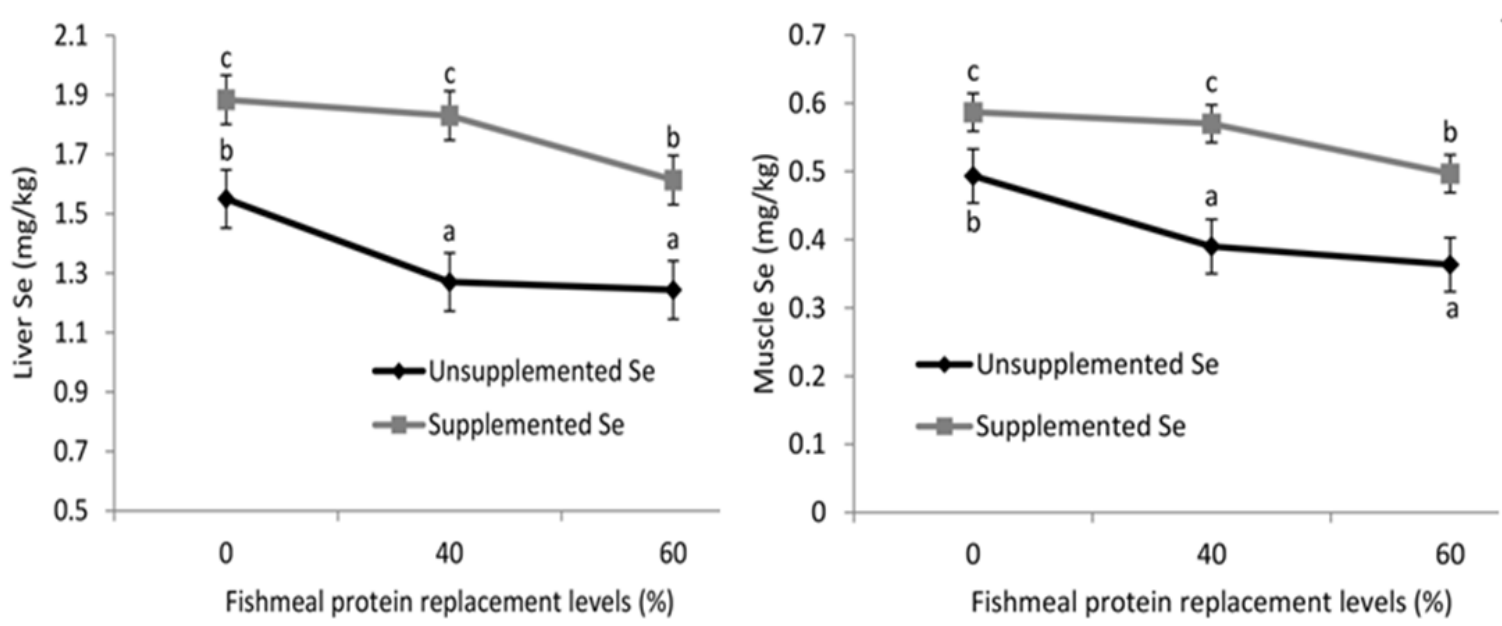

Figure 1. Mean of Se concentrations in the muscle and liver tissues of cobia fed diets containing various inclusion levels of lupin kernel meal with and without Se supplementation, mean with different letters are significantly different $(\mathrm{P}<0.05)$

One possible reason for the reduced nutrient digestibility in cobia fed lupin-based diets could be the presence of oligosaccharides in the diets. The narrow-leafed LKM contains relatively high levels of oligosaccharides in the forms of raffinose, stachyose and verbascose (Glencross, 2001; Petterson, 2000). These anti-nutrients may interact with the digestion of other nutrients (van Barneveld, 1999). They also prevent the activity of digestive enzymes and substrate transportation in the intestine (Francis et al., 2001), thus reducing nutrient digestibility as seen in rainbow trout (Glencross, Boujard, \& Kaushik, 2003) and Atlantic salmon (Refstie, Storebakken, \& Roem, 1998). Lupin meal also contains a significant amount of carbohydrates (Gatlin et al., 2007). A carnivorous fish such as cobia poorly utilise dietary carbohydrate as an energy source (Ren, Ai, Mai, Ma, \& Wang, 2011), resulting in low energy digestibility. In contrast, cobia fed dietary LKM supplemented with organic Se showed improved growth, feed efficiency and nutrient digestibility compared with the fish fed diets lacking Se supplementation. A positive relationship between nutrient digestibility and dietary Se supplementation has been demonstrated in pigs (Chaudhary, Garg, Mittal, \& Mudgal, 2010) and sheep (Shi et al., 2011). The reason for this could be due to the increased quantity and activities of digestive enzymes induced by dietary Se (Chaudhary et al., 2010). However, the effects of interaction between dietary Se and plant-derived protein on feed efficiency and nutrient digestibility has been reported in only one study, in which barramundi showed increased protein digestibility after being fed Se-supplemented lupin-based diets (Ilham et al., 2016). In the case of soybean, African catfish fed plant-based diets with supplemented Se demonstrated increased activities of protein metabolism enzymes and FI (Abdel-Tawwab et al., 2007). This could be indirectly associated with the complex mechanism of amino acid-chelated Se (AAC-Se) ingestion, resulting in increased essential trace element sources when high AAC-Se is absorbed into mucosal tissues (Ilham et al., 2016). These elements act as a cofactor in the synthesis of hydrolytic enzymes, such as gastrointestinal GPx, which plays important roles in defending the intestinal mucosal integrity (Lindh, 2013), stimulating nutrient digestion in fish (Ilham et al., 2016).

The dietary Se requirement has been established for juvenile cobia using purified diet (Liu et al., 2010). However, the biological effects of dietary Se on the feed utilisation efficiency of plant-derived ingredients, such as LKM, in this species are still unknown. In the current study, though increased levels of dietary LKM resulted in a corresponding decrease in dietary Se levels, the minimum dietary Se was still higher than threshold requirement for cobia fed casein-based diet (Liu et al., 2010). However, the improved growth and feed utilisation efficiency in cobia fed supplemental Se lupin-based diets indicated that the endogenous dietary Se in the lupin-based diets may not meet the nutritional requirement for juvenile cobia.

Feed ingredients contain a varied amount of Se, with a higher availability of Se from plant-derived ingredients 
than from fishmeal (Watanabe et al., 1997). Thus, casein is generally used as the sole protein source in purified or semi-purified diets to overcome the complications of the varied Se availabilities in feed ingredients (Hilton, Hodson, \& Slinger, 1980; Lin, 2014; Lin \& Shiau, 2005; Liu et al., 2010). However, the use of casein, compared with fishmeal or krill meal, in commercial diets becomes challenging due to its high price and poor feed intake and growth rates (Hertrampf \& Piedad-Pascual, 2000). Further, in the current study, the SGR was $74 \%$ higher when fed the control diet containing various protein ingredients than reported by Liu et al. (2010) in the cobia fed a casein-based diet. The higher metabolic rates associated with faster-growing fish require sufficient energy to maximize their growth potential (DeVries \& Eastman, 1981), resulting in a need to take up more nutrients, including Se.

The optimum dietary Se concentrations quantified for most fish species fed casein-based diets ranged from 0.15 to $0.98 \mathrm{mg} / \mathrm{kg}$ (Hilton et al., 1980; Lin, 2014; Lin \& Shiau, 2005; Liu et al., 2010). Meanwhile, fish fed fishmeal or plant meal-based diets resulted in relatively higher dietary Se requirement levels, ranging from 1.62 to 5.35 $\mathrm{mg} / \mathrm{kg}$ (Abdel-Tawwab et al., 2007; Le \& Fotedar, 2013; Zhu et al., 2012). Even though, fishmeal-based diets can provide adequate Se to meet the nutritional requirements of some species (Watanabe et al., 1997). However, the significantly lower Se digestibility from fishmeal (38.48 - $47 \%$ ) compared with SeMet or Se-yeast (89.48 $92 \%$ ) (Le \& Fotedar, 2014; Watanabe et al., 1997) and relatively lower concentration of Se in lupin kernel meal $(0.35 \mathrm{mg} / \mathrm{kg})$ than fishmeal $(4.37 \mathrm{mg} / \mathrm{kg})$ may result in Se deficiency when fishmeal protein is replaced with lupin kernel protein, as seen in barramundi (Ilham et al., 2016) and cobia as in the current study. Moreover, Barrows et al. (2010) and Read et al. (2014) also indicated that rainbow trout fed plant-based diets required macro-minerals and inositol and/or dietary copper and zinc supplementation at higher levels to improve growth performance than those previously quantified by the NRC (1993). Similarly, the beneficial effects of Se fortification were also observed in African catfish fed soybean-based diets (Abdel-Tawwab et al., 2007) and barramundi fed plant-based diets (Ilham et al., 2016). This may be, in part, a reason for the enhancement of growth and feed utilisation performances in the current study.

The values of $\mathrm{RBC}$ and $\mathrm{Hb}$ can provide useful information about oxidative stress and toxicological impacts in fish as their important roles on physiological functions in fish (Kiron, Puangkaew, Ishizaka, Satoh, \& Watanabe, 2004). In this study, reduced $\mathrm{Hb}$ and $\mathrm{RBCs}$ concentrations were shown in cobia fed dietary lupin meal without Se supplementation. This is consistent with a previous report in cobia (Zhou et al., 2005) fed soybean-based diets. The restriction on $\mathrm{RBCs}$ production and $\mathrm{Hb}$ synthesis imposed by adverse effects of anti-nutrients, as previously reported in cobia (Zhou et al., 2005), could constitute the reason. Conversely, cobia fed dietary lupin meal supplemented with Se did not show any significant differences in haematological performance compared with fish fed the control diet. As RBC and Hb play significant roles in oxygen and carbon dioxide transportation in the blood and haemoglobin synthesis (Olugbemi, Mutayoba, \& Lekule, 2010). The increases in the RBC and Hb values in the cobia fed lupin-based diets supplemented with Se can be attributed to the enhancement of fish health stimulated by Se supplementation, as described in other fish species (Abdel-Tawwab et al., 2007; Ilham et al., 2016).

In the current study, dietary LKM did not have any effects on protein, ash and dry matter levels in the muscles of cobia, irrespective of Se supplementation. This is consistent with the study in gilthead sea bream Sparus aurata (Pereira \& Oliva-Teles, 2004) and black seabream Acanthopagrus schlegeli (Zhang et al., 2012) fed lupin inclusion diets. A deficiency of taurine in plant-based diets has been linked to the reduced lipid deposition in the tissues of cobia (Lunger, McLean, Gaylord, Kuhn, \& Craig, 2007). However, in the current study, taurine was added at $5 \mathrm{~g} / \mathrm{kg}$ to satisfy the nutritional needs of cobia as quantified by Watson et al. (2014). Thus, the reduced muscle lipid contents of cobia fed $315 \mathrm{~g} / \mathrm{kg}$ LKM diet in the current study might be due to the low energy intake and energy digestibility, similar in cobia fed other plant-derived ingredients (Luo et al., 2012; Luo et al., 2013; Zhou et al., 2005). As the tissue Se depositions of cobia had a strong linear relationship with dietary Se levels, the concentration of Se in these tissues can be used as a biomarker of dietary Se delineation.

In conclusion, cobia fed a lupin-based diet requires Se fortification to meet their nutritional requirements to satisfy potential growth and feed utilisation. Up to $210 \mathrm{~g} / \mathrm{kg}$ of LKM can be included in the diets of cobia with Se supplementation, without impairing growth, feed efficiency and physiological performances. The dietary Se supplement had no beneficial effects on the muscle composition and amino acid profiles of cobia, but significantly improved their haematological parameters and nutrient digestibility.

\section{Acknowledgements}

The research was sponsored by $\mathrm{PhD}$ program of Curtin International Postgraduate Research Scholarships (CIPRS) in conjunction with Ministry of Education and Training Vietnam (MoET) Award. 


\section{References}

Abdel-Tawwab, M., Mousa, M. A. A., \& Abbass, F. E. (2007). Growth performance and physiological response of African catfish, Clarias gariepinus (B.) fed organic selenium prior to the exposure to environmental copper toxicity. Aquaculture, 272(1-4), 335-345. http://dx.doi.org/10.1016/j.aquaculture.2007.09.004

Antony Jesu Prabhu, P., Schrama, J. W., \& Kaushik, S. J. (2014). Mineral requirements of fish: A systematic review. Reviews in Aquaculture, N/A-N/A. http://dx.doi.org/10.1111/raq.12090

AOAC. (1990). Official methods of analysis of the Association of Official Analytical Chemists (15th Ed.). Arlington, Virginia, USA. The Association of Official Analytical Chemists, pp. 1298.

Barrows, F. T., Gaylord, T. G., Sealey, W. M., Smith, C. E., \& Porter, L. (2010). Supplementation of plant-based diets for rainbow trout (Oncorhynchus mykiss) with macro-minerals and inositol. Aquaculture Nutrition, 16(6), 654-661. http://dx.doi.org/10.1111/j.1365-2095.2009.00717.x

Bolin, D. W., King, R. P., \& Klosterman, E. W. (1952). A simplified method for the determination of chromic oxide (Cr 2O3) when used as an index substance. Science, 116(3023), 634-635.

Carter, C. G., \& Hauler, R. C. (2000). Fish meal replacement by plant meals in extruded feeds for Atlantic salmon, Salmo salar L. Aquaculture, 185(3-4), 299-311. http://dx.doi.org/10.1016/S0044-8486(99)00353-1

Chaudhary, M., Garg, A. K., Mittal, G. K., \& Mudgal, V. (2010). Effect of organic selenium supplementation on growth, Se uptake, and nutrient utilization in Guinea pigs. Biological Trace Element Research, 133(2), 217-226. http://dx.doi.org/10.1007/s12011-009-8420-z

Cho, C. Y., Slinger, S. J., \& Bayley, H. S. (1982). Bioenergetics of salmonid fishes: Energy intake, expenditure and productivity. Comparative Biochemistry and Physiology Part B: Comparative Biochemistry, 73(1), 25-41. http://dx.doi.org/10.1016/0305-0491(82)90198-5

Chou, R. L., Her, B. Y., Su, M. S., Hwang, G., Wu, Y. H., \& Chen, H. Y. (2004). Substituting fish meal with soybean meal in diets of juvenile cobia Rachycentron canadum. Aquaculture, 229(1-4), 325-333. http://dx.doi.org/10.1016/s0044-8486(03)00395-8

DeVries, A. L., \& Eastman, J. T. (1981). Physiology and ecology of notothenioid fishes of the Ross Sea. Journal of Royal Society of New Zealand, 11(4), 329-340.

Embaby, H. E. S. (2011). Effect of heat treatments on certain antinutrients and in vitro protein digestibility of peanut and sesame seeds. Food Science and Technology Research, 17(1), 31-38. http://dx.doi.org/10.3136/fstr.17.31

Espe, M., El-Mowafi, A., \& Ruohonen, K. (2012). Replacement of Fishmeal with Plant Protein Ingredients in Diets to Atlantic Salmon (Salmo salar) - Effects on Weight Gain and Accretion. In Z. A. Muchlisin (Ed.), Aquaculture: InTech.

Farhangi, M., \& Carter, C. G. (2001). Growth, physiological and immunological responses of rainbow trout (Oncorhynchus Mykiss) to different dietary inclusion levels of dehulled lupin (Lupinus angustifolius). Aquaculture Research, 32, 329-340. http://dx.doi.org/10.1046/j.1355-557x.2001.00044.x

Folch, J., Lees, M., \& Sloane-Stanley, G. H. (1957). A simple method for the isolation and purification of total lipides from animal tissues. Journal of Biological Chemistry, 226(1), 497-509.

Fontagné-Dicharry, S., Godin, S., Liu, H., Antony Jesu Prabhu, P., Bouyssière, B., Bueno, M., . . Kaushik, S. J. (2015). Influence of the forms and levels of dietary selenium on antioxidant status and oxidative stress-related parameters in rainbow trout (Oncorhynchus Mykiss) fry. British Journal of Nutrition, 113(12), 1876-1887. http://dx.doi.org/10.1017/S0007114515001300

Francis, G., Makkar, H. P. S., \& Becker, K. (2001). Antinutritional factors present in plant-derived alternate fish feed ingredients and their effects in fish. Aquaculture, 199(3-4), 197-227. http://dx.doi.org/10.1016/s0044-8486 (01) 00526-9

Fraser, T. W. K., \& Davies, S. J. (2009). Nutritional requirements of cobia, Rachycentron canadum (Linnaeus): A review. Aquaculture Research, 40(11), 1219-1234. http://dx.doi.org/10.1111/j.1365-2109.2009.02215.x

Gatlin, D. M., Barrows, F. T., Brown, P., Dabrowski, K., Gaylord, T. G., Hardy, R. W. ... Wurtele, E. (2007). Expanding the utilization of sustainable plant products in aquafeeds: A review. Aquaculture Research, 38(6), 551-579. http://dx.doi.org/10.1111/j.1365-2109.2007.01704.x

Glencross, B. (2001). Feeding lupins to fish: A review of the nutritional and biological value of lupins in 
aquaculture feeds. North Beach, W.A: Dept. of Fisheries, Research Division.

Glencross, B., Boujard, T., \& Kaushik, S. (2003). Influence of oligosaccharides on the digestibility of lupin meals when fed to rainbow trout, Oncorhynchus Mykiss. Aquaculture, 219(1-4), 703-713. http://dx.doi.org/10.1016/S0044-8486(02)00664-6

Haddad, J., Greiner, R., \& Allaf, K. (2007). Effect of instantaneous controlled pressure drop on the phytate content of lupin. LWT - Food Science and Technology, 40(3), 448-453. http://dx.doi.org/10.1016/j.lwt.2006.02.008

Hertrampf, J. W., \& Piedad-Pascual, F. (2000). Handbook on ingredients for aquaculture feeds. Netherlands: Kluwer Academic Publishser.

Hilton, J. W., Hodson, P. V., \& Slinger, S. J. (1980). The requirement and toxicity of selenium in rainbow trout (Salmo Gairdneri). The Journal of Nutrition, 110(12), 2527-2535.

Ilham, Fotedar, R., \& Munilkumar, S. (2016). Effects of organic selenium supplementation on growth, glutathione peroxidase activity and histopathology in juvenile barramundi (Lates Calcarifer Bloch, 1970) fed high lupin meal-based diets. Aquaculture, 457, 15-23. http://dx.doi.org/10.1016/j.aquaculture.2016.02.003

Jobling, M., Covés, D., Damsgård, B., Kristiansen, H. R., Koskela, J., Petursdottir, T. E. ... Gudmundsson, O. (2007). Techniques for measuring feed intake. In D. Houlihan, T. Boujard, \& M. Jobling (Eds.), Food Intake in Fish, 87, Blackwell Science Ltd.

Kim, J. D., Tibbetts, S. M., Milley, J. E., \& Lall, S. P. (2007). Effect of the incorporation level of dehulled soybean meal into test diet on apparent digestibility coefficients for protein and energy by juvenile haddock, $\begin{array}{lllll}\text { Melanogrammus aeglefinus } & \text { L. } & \text { Aquaculture, } & \text { 267(1-4), }\end{array}$ $\mathrm{http}: / / \mathrm{dx}$.doi.org/10.1016/j.aquaculture.2007.02.052

Kiron, V., Puangkaew, J., Ishizaka, K., Satoh, S., \& Watanabe, T. (2004). Antioxidant status and nonspecific immune responses in rainbow trout (Oncorhynchus mykiss) fed two levels of vitamin $\mathrm{E}$ along with three lipid sources. Aquaculture, 234(1-4), 361-379. http://dx.doi.org/10.1016/j.aquaculture.2003.11.026

Le, K. T., \& Fotedar, R. (2013). Dietary selenium requirement of yellowtail kingfish (Seriola lalandi). Agricultural Science, 4(6A), 68-75.

Le, K. T., \& Fotedar, R. (2014). Bioavailability of selenium from different dietary sources in yellowtail kingfish (Seriola lalandi). Aquaculture, 420-421(0), 57-62. http://dx.doi.org/10.1016/j.aquaculture.2013.10.034

Lin, Y. H. (2014). Effects of dietary organic and inorganic selenium on the growth, selenium concentration and meat quality of juvenile grouper, Epinephelus Malabaricus. Aquaculture, 430(0), 114-119. http://dx.doi.org/10.1016/j. aquaculture.2014.03.048

Lin, Y. H., \& Shiau, S.-Y. (2005). Dietary selenium requirements of juvenile grouper, Epinephelus Malabaricus. Aquaculture, 250(1-2), 356-363. http://dx.doi.org/10.1016/j.aquaculture.2005.03.022

Lindh, U. (2013). Biological Functions of the Elements. In O. Selinus (Ed.), Essentials of Medical Geology: Revised Edition, 129-177. Dordrecht: Springer Netherlands.

Liu, K., Wang, X. J., Ai, Q., Mai, K., \& Zhang, W. (2010). Dietary selenium requirement for juvenile cobia, Rachycentron Canadum L. Aquaculture Research, 41(10), 594-601. http://dx.doi.org/10.1111/j.1365-2109.2010.02562.x

Lunger, A. N., Craig, S. R., \& McLean, E. (2006). Replacement of fish meal in cobia (Rachycentron Canadum) diets using an organically certified protein. Aquaculture, 257(1-4), 393-399. http://dx.doi.org/10.1016/j.aquaculture.2005.11.010

Lunger, A. N., McLean, E., Gaylord, T. G., Kuhn, D., \& Craig, S. R. (2007). Taurine supplementation to alternative dietary proteins used in fish meal replacement enhances growth of juvenile cobia (Rachycentron Canadum). Aquaculture, 271(1-4), 401-410. http://dx.doi.org/10.1016/j.aquaculture.2007.07.006

Luo, Y., Ai, Q., Mai, K., Zhang, W., Xu, W., \& Zhang, Y. (2012). Effects of dietary rapeseed meal on growth performance, digestion and protein metabolism in relation to gene expression of juvenile cobia $\begin{array}{llll}\text { (Rachycentron } \quad \text { Canadum). } & \text { Aquaculture, } & \text { 368-369(0), }\end{array}$ http://dx.doi.org/10.1016/j.aquaculture.2012.09.013

Luo, Y., Ai, Q., Mai, K., Zhang, W., Xu, W., Zhang, Y., \& Liufu, Z. (2013). Effects of dietary corn gluten meal 
on growth performance and protein metabolism in relation to IGF-I and TOR gene expression of juvenile cobia (Rachycentron Canadum). Journal of Ocean University of China, 12(3), 418-426. http://dx.doi.org/10.1007/s11802-013-2021-3

NRC, N. R. C. (1993). Nutrient Requirements of Fish. Washington, DC, USA: National Academies Press.

Olsen, R. L., \& Hasan, M. R. (2012). A limited supply of fishmeal: Impact on future increases in global aquaculture production. Trends in Food Science \& Technology, 27(2), 120-128. http://dx.doi.org/10.1016/j.tifs.2012.06.003

Olugbemi, T. S., Mutayoba, S. K., \& Lekule, F. P. (2010). Effect of Moringa (Moringa oleifera) inclusion in cassava based diets fed to broiler chickens. International Journal of Poultry Science, 9(4), 363-367.

Pereira, T. G., \& Oliva-Teles, A. (2004). Evaluation of micronized lupin seed meal as an alternative protein source in diets for gilthead sea bream, Sparus Aurata L. Juveniles. Aquaculture Research, 35(9), 828-835. http://dx.doi.org/10.1111/j.1365-2109.2004.01073.x

Petterson, D. S. (2000). The use of lupins in feeding systems - review. Asian Australas J. Anim. Sci, 13(6), 861-882. http://dx.doi.org/10.5713/ajas.2000.861

Read, E. S., Barrows, F. T., Gibson Gaylord, T., Paterson, J., Petersen, M. K., \& Sealey, W. M. (2014). Investigation of the effects of dietary protein source on copper and zinc bioavailability in fishmeal and plant-based diets for rainbow trout. Aquaculture, 432, 97-105. http://dx.doi.org/10.1016/j.aquaculture.2014.04.029

Refstie, S., Glencross, B., Landsverk, T., Sørensen, M., Lilleeng, E., Hawkins, W., \& Krogdahl, Å. (2006). Digestive function and intestinal integrity in Atlantic salmon (Salmo Salar) fed kernel meals and protein concentrates made from yellow or narrow-leafed lupins. Aquaculture, 261(4), 1382-1395. http://dx.doi.org/10.1016/j.aquaculture.2006.07.046

Refstie, S., Storebakken, T., \& Roem, A. J. (1998). Feed consumption and conversion in Atlantic salmon (Salmo Salar) fed diets with fish meal, extracted soybean meal or soybean meal with reduced content of oligosaccharides, trypsin inhibitors, lectins and soya antigens. Aquaculture, 162(3-4), 301-312. http://dx.doi.org/10.1016/S0044-8486 (98) 00222-1

Ren, M., Ai, Q., Mai, K., Ma, H., \& Wang, X. (2011). Effect of dietary carbohydrate level on growth performance, body composition, apparent digestibility coefficient and digestive enzyme activities of juvenile cobia, Rachycentron Canadum L. Aquaculture Research, 42(10), 1467-1475. http://dx.doi.org/10.1111/j.1365-2109.2010.02739.x

Robaina, L., Izquierdo, M. S., Moyano, F. J., Socorro, J., Vergara, J. M., Montero, D., \& Fernández-Palacios, H. (1995). Soybean and lupin seed meals as protein sources in diets for gilthead seabream (Sparus Aurata): Nutritional and histological implications. Aquaculture, 130(2-3), 219-233. http://dx.doi.org/10.1016/0044-8486 (94) 00225-D

Salze, G., McLean, E., Battle, P. R., Schwarz, M. H., \& Craig, S. R. (2010). Use of soy protein concentrate and novel ingredients in the total elimination of fish meal and fish oil in diets for juvenile cobia, Rachycentron Canadum. Aquaculture, 298(3-4), 294-299. http://dx.doi.org/10.1016/j.aquaculture.2009.11.003

Satoh, S., Poe, W. E., \& Wilson, R. P. (1989). Effect of supplemental phytate and/or tricalcium phosphate on weight gain, feed efficiency and zinc content in vertebrae of channel catfish. Aquaculture, 80(1), 155-161. http://dx.doi.org/10.1016/0044-8486(89)90281-0

Shi, L., Xun, W., Yue, W., Zhang, C., Ren, Y., Liu, Q. ... Shi, L. (2011). Effect of elemental nano-selenium on feed digestibility, rumen fermentation, and purine derivatives in sheep. Animal Feed Science and Technology, 163(2-4), 136-142. http://dx.doi.org/10.1016/j.anifeedsci.2010.10.016

Storebakken, T., Shearer, K. D., \& Roem, A. J. (1998). Availability of protein, phosphorus and other elements in fish meal, soy-protein concentrate and phytase-treated soy-protein-concentrate-based diets to Atlantic salmon. Salmo Salar. Aquaculture, 161(1-4), 365-379. http://dx.doi.org/10.1016/S0044-8486(97)00284-6

Tacon, A. G. J., \& Metian, M. (2008). Global overview on the use of fish meal and fish oil in industrially compounded aquafeeds: Trends and future prospects. Aquaculture, 285(1-4), 146-158. http://dx.doi.org/10.1016/j.aquaculture.2008.08.015

Trushenski, J., Laporte, J., Lewis, H., Schwarz, M., Delbos, B., Takeuchi, R., \& Sampaio, L. A. (2011). Fish meal replacement with soy-derived protein in feeds for juvenile cobia: Influence of replacement level and 
attractant supplementation. Journal of the World Aquaculture Society, 42(3), 435-443. http://dx.doi.org/10.1111/j.1749-7345.2011.00484.x

van Barneveld, R. J. (1999). Understanding the nutritional chemistry of lupin (Lupinus Spp.) seed to improve livestock production efficiency. Nutrition Research Reviews, 12(02), 203-230. http://dx.doi.org/10.1079/095442299108728938

Watanabe, T., Kiron, V., \& Satoh, S. (1997). Trace minerals in fish nutrition. Aquaculture, 151(1-4), 185-207. http://dx.doi.org/10.1016/S0044-8486 (96) 01503-7

Watson, A. M., Barrows, F. T., \& Place, A. R. (2014). Effects of Graded Taurine Levels on Juvenile Cobia. North American Journal of Aquaculture, 76(3), 190-200. http://dx.doi.org/10.1080/15222055.2014.899531

Zhang, Y., Øverland, M., Xie, S., Dong, Z., Lv, Z., Xu, J., \& Storebakken, T. (2012). Mixtures of lupin and pea protein concentrates can efficiently replace high-quality fish meal in extruded diets for juvenile black sea $\begin{array}{lllll}\text { bream } \quad \text { (Acanthopagrus } & \text { Schlegeli). } & \text { Aquaculture, } & \text { 354-355(0), }\end{array}$ http://dx.doi.org/10.1016/j.aquaculture.2012.03.038

Zhou, Q. C., Mai, K. S., Tan, B. P., \& Liu, Y. J. (2005). Partial replacement of fishmeal by soybean meal in diets for juvenile cobia (Rachycentron Canadum). Aquaculture Nutrition, 11(3), 175-182. http://dx.doi.org/10.1111/j.1365-2095.2005.00335.x

Zhou, Q. C., Wu, Z. H., Chi, S. Y., \& Yang, Q. H. (2007). Dietary lysine requirement of juvenile cobia $\begin{array}{llll}\text { (Rachycentron Canadum). } & \text { Aquaculture, }\end{array}$ http://dx.doi.org/10.1016/j.aquaculture.2007.08.056

Zhou, Q. C., Wu, Z. H., Tan, B. P., Chi, S. Y., \& Yang, Q. H. (2006). Optimal dietary methionine requirement for Juvenile Cobia (Rachycentron Canadum). Aquaculture, 258(1-4), 551-557. http://dx.doi.org/10.1016/j.aquaculture.2006.03.035

Zhu, Y., Chen, Y., Liu, Y., Yang, H., Liang, G., \& Tian, L. (2012). Effect of dietary selenium level on growth performance, body composition and hepatic glutathione peroxidase activities of largemouth bass $\begin{array}{llll}\text { Micropterus Salmoide. Aquaculture } & \text { Research, 43(11), }\end{array}$ http://dx.doi.org/10.1111/j.1365-2109.2011.02972.x

\section{Copyrights}

Copyright for this article is retained by the author(s), with first publication rights granted to the journal.

This is an open-access article distributed under the terms and conditions of the Creative Commons Attribution license (http://creativecommons.org/licenses/by/4.0/). 